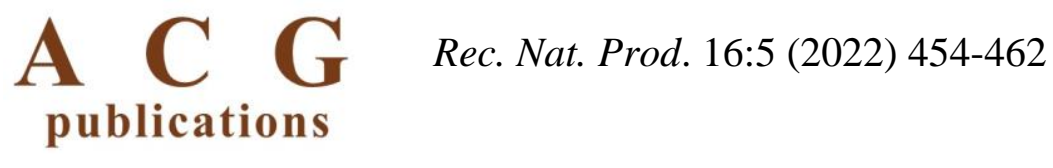

records of natural products

\title{
Cytotoxic Diterpenoids from Scoparia dulcis
}

\author{
Lirong Wang $\oplus^{1}$, Jie Yu $\oplus^{2}$, Zonglong Nie $\oplus^{2}$ and Peipei Shan $\oplus^{1 *}$ \\ ${ }^{1}$ Institute of Translational Medicine, The Affiliated Hospital of Qingdao University, College of \\ Medicine, Qingdao University, Qingdao 266021, China \\ ${ }^{2}$ Qingdao Central Hospital, Qingdao 266042, China
}

(Received November 18, 2021; Revised January 10, 2022; Accepted January 14, 2022)

\begin{abstract}
A new scopadulane-type diterpenoid (1) and one known labdane-type diterpenoid (2) have been isolated from the whole plants of a traditional medicinal plant, Scoparia dulcis. Their structures were established mainly by spectroscopic methods, and the absolute configuration of compound $\mathbf{1}$ has been determined by quantum chemical calculation of the electronic circular dichroism (ECD) spectrum and comparison with the experimental one. The cytotoxicity of $\mathbf{1}$ and $\mathbf{2}$ against two breast cancer cell lines (MCF-7 and MDA-MB231) and a cervical cancer cell line (Hela) were tested, and only compound $\mathbf{2}$ displayed inhibitory activities against these cells with $\mathrm{IC}_{50}$ values ranging from 8.1 to $45.2 \mu \mathrm{M}$, while compound $\mathbf{1}$ were inactive. In addition, compound 2 also showed in vitro anti-tumor activity against MCF-7, MDA-MB231, and Hela cells in a concentration-dependent manner.
\end{abstract}

Keywords: Scoparia dulcis, Scrophulariaceae; scopadulane diterpenoid; labdane diterpenoid; cytotoxicity. (C) 2022 ACG Publications. All rights reserved.

\section{Introduction}

Scoparia dulcis is a herbaceous plant or small shrub originating from the tropical areas of America, and it is now widely distributed in tropical regions all over the world [1]. As the only Scoparia species found in China, S. dulcis has been mainly collected and applied in local ethno medicine by the Dai people in Yunnan Province and the Zhuang people in Guangxi Zhuang Autonomous region, and its major indications include cough, sore throat and edema [2]. Previous studies on the pharmacological effects of the solvent extracts (mainly water or ethanol) of $S$. dulcis revealed a variety of bioactivities such as anti-diabetes $[3,4]$, anti-inflammation $[5,6]$ and antioxidation [7,8]. In addition, modern phytochemical investigations on this herb have shown that it is a rich source of diverse secondary metabolites especially diterpenoids with cytotoxic [9-12], cell viability attenuating [13-15], antiviral [16,17] and antidiabetic [18,19] activities. Flavonoids with antidiabetic [19-22], NGF potentiating [23] and cytotoxic [24] properties, as well as immunomodulatory triterpenoids [25] and antiproliferative alkaloids [26], have also been reported. In a very recent review [27], Wen and co-workers have presented a comprehensive record on the phytochemistry and pharmacology of $S$. dulcis.

In our current project to search new cytotoxic agents from medicinal plants for future potential anticancer lead compounds, an intensive fractionation of the $95 \%$ ethanol extract of the whole plants of $S$. dulcis has led to the separation of one new scopadulane-type diterpenoid ( $1 \beta$-Hydroxydulcinol, 1) and one known labdane-type diterpenoid (scoparinol, 2). The present paper deals with the isolation, structure characterization, and primary anti-tumor evaluation of the two diterpenoids.

*Corresponding author: E-mail: shanpeipei@qdu.edu.cn 


\section{Materials and Methods}

\subsection{General Experimental Procedures}

Optical rotations were recorded on a Rudolph V polarimeter (Rudolph Research Analytical, Hackettstown, USA). ECD experiments were carried out on a Chirascan photospectrometer (Applied Photophysics Ltd., Leatherhead, UK). NMR spectra in $\mathrm{CDCl}_{3}$ (reference signal: $\delta_{\mathrm{H}} 7.26, \delta_{\mathrm{C}} 77.16$ ) were acquired on a Bruker Avance DRX600 spectrometer (Bruker BioSpin AG, Fallanden, Switzerland). ESIMS and HR-ESIMS analyses were conducted on Agilent 1260-6460 Triple Quad and 6545 Q-TOF MS spectrometers, respectively (Agilent Technologies Inc., Waldbronn, Germany). HPLC analyses and separations were performed on an Agilent 1260 series LC instrument (Agilent Technologies Inc., Waldbronn, Germany) equipped with an $\mathrm{SB}-\mathrm{C}_{18}$ column $(9.4 \times 250 \mathrm{~mm}$, Agilent Technologies Inc., Santa Clara, USA). Reversed phase $\mathrm{C}_{18}$ (RP-18) silica gel (Merck KGaA, Darmstadt, Germany), Sephadex LH-20 (GE Healthcare Bio-Sciences AB, Uppsala, Sweden), MCI gel (CHP20/P120, Mitsubishi Chemical Co. Ltd., Tokyo, Japan) and silica gel (300-400 mesh; Qingdao Marine Chemical Co. Ltd., Qingdao, China) were used for column chromatography (CC). Solvents used for CC were of at least analytical grade (Sinopharm Chemical Reagent Co. Ltd., Beijing, China) and solvents used for HPLC were of HPLC grade (Oceanpak Alexative Chemical Ltd., Goteborg, Sweden). Pre-coated silica gel $\mathrm{GF}_{254}$ plates (Yantai Huiyou Chemical Co. Ltd., Yantai, China) were used for thin layer chromatography (TLC) monitoring.

\subsection{Plant Materials}

The whole plants of Scoparia dulcis L. were harvested in Aug. 2018 in Xishuangbanna of Yunnan province, China, and were authenticated by Prof. Wanyi Li from Yunnan Academy of Agricultural Sciences. The plant materials were compared to a previously collected local specimen (IMDY0020482). A voucher specimen is also deposited at the herbal repository room of the College of Medicine, Qingdao University (No.: SL-2018-01).

\subsection{Extraction and Isolation}

The dried whole plants $(10 \mathrm{~kg})$ of $S$. dulcis were powdered and percolated with $95 \%$ ethanol at room temperature $(3 \times 7$ days), and the solutions were combined and evaporated under vacuum to yield the crude extract $(800 \mathrm{~g})$. The crude extract was partitioned between water $(1.5 \mathrm{~L})$ and ethyl acetate $(1.0 \mathrm{~L} \times 3)$ to give the ethyl acetate soluble part, which $(210 \mathrm{~g})$ was solvent-removed and then fractionated by MCI gel CC eluted with $\mathrm{MeOH}-\mathrm{H}_{2} \mathrm{O}(30 \%, 50 \%, 80 \%$, and 95\%) to obtain four elutions (A, B, C and D).

Fraction C (42 g) was subjected to a silica gel column, eluted with petroleum ether/ethyl acetate (from 10/1 to 0/1), to return eight fractions (C1-C8). Then fraction C4 (1.8 g) was separated by RP-18 CC using 80\%-95\% methanol/water as eluting solvent to give six subfractions (C4-1-C4-6). Fraction C4-2 was processed successively by silica gel CC (dichloromethane/methanol, from 100/1 to 50/1) and semi-preparative HPLC $\left(80 \% \mathrm{MeCN} / \mathrm{H}_{2} \mathrm{O}\right)$ to yield compound $1\left(3.9 \mathrm{mg}, t_{\mathrm{R}}=14.0 \mathrm{~min}\right)$. The fraction C6 (5.6 g) was chromatographed on a RP-18 column $\left(\mathrm{MeOH} / \mathrm{H}_{2} \mathrm{O}, 60 \%-80 \%\right)$ to give five subfractions (C6-1-C6-5). Subfraction C6-2 was first fractionated by Sephadex LH-20 CC (dichloromethane/methanol, 3/2) and then purified by semi-preparative HPLC $\left(85 \% \mathrm{MeOH} / \mathrm{H}_{2} \mathrm{O}\right)$ to afford compound $2\left(5.4 \mathrm{mg}, t_{\mathrm{R}}=11.6 \mathrm{~min}\right)$

1 $\beta$-Hydroxydulcinol (1): White powder; $[\alpha]^{24} \mathrm{D}-5.7(c 0.33, \mathrm{MeOH}) ; \mathrm{UV}(\mathrm{MeOH}) \lambda(\log \varepsilon) 230(3.93)$ $\mathrm{nm}$; ECD $(c 0.02, \mathrm{MeOH}) \lambda(\Delta \varepsilon) 200(+4.4), 210(-1.5) 230(+9.3), 294(+2.1) ;{ }^{1} \mathrm{H}$ and ${ }^{13} \mathrm{C}$ NMR see Table 1; ESIMS m/z 463.2 [M + Na $]^{+}, 903.4[2 \mathrm{M}+\mathrm{Na}]^{+}$; HR-ESIMS $m / z$ 441.2654 [M + H] $]^{+}$, (calcd for $\mathrm{C}_{27} \mathrm{H}_{37} \mathrm{O}_{5}^{+}$, 441.2636). 
Cytotoxic diterpenoids from the whole plants of Scoparia dulcis

\subsection{ECD Calculations}

The theoretical ECD spectra of compound $\mathbf{1}$ and its enantiomer were acquired by Timedependent Density Functional Theory (TD-DFT) method as described formerly [28].

\subsection{Bioassays}

\subsubsection{Cell Viability Assay}

The cell viability assay was performed as previously reported [29]. Briefly, MCF-7, MDAMB231 and HeLa cells $\left(5 \times 10^{3}\right.$ cells/well) were seeded in 96-well plates. After $24 \mathrm{~h}$, cells were treated with different concentrations of compound $\mathbf{2}$ or SAHA. Cell viability was measured by MTS assay, the Aqueous one Solution (Promega) was used according to the manufacturer's instructions, and the absorption at $490 \mathrm{~nm}$ was measured.

\subsubsection{Colony Formation Assay}

The colony formation assay was performed as previously reported [30]. MDA-MB231 and HeLa cells were seeded in a 6-well plate, and $24 \mathrm{~h}$ later, cells were treated with different concentrations of compound 2. The culture medium was refreshed every other day. Cells were cultured for 10 days. Then the clones were fixed with $4 \%$ paraformaldehyde, stained with $0.1 \%$ crystal violet, and counted manually.

\subsubsection{Cell Death Assay}

MDA-MB231 and MCF-7 cells were seeded in a 6-well plate, and $24 \mathrm{~h}$ later, cells were treated with different concentrations of compound 2 , and $24 \mathrm{~h}$ later, the cell morphology changes were detected by phase-contrast microscope (Olympus, Tokyo, Japan).

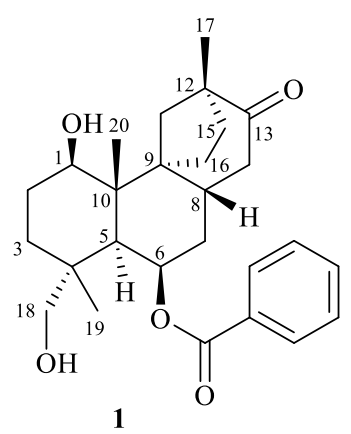<smiles>C=C1C[C@H](OC(=O)c2ccccc2)[C@H](C)[C@@]2(C)C(C)(CO)CCC[C@]12CC/C(C)=C/CO</smiles>

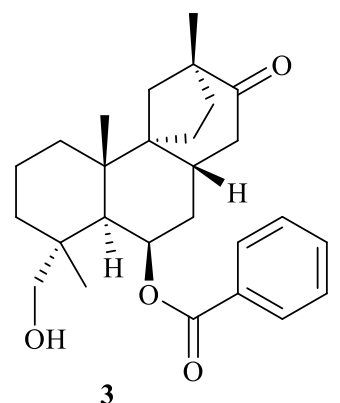

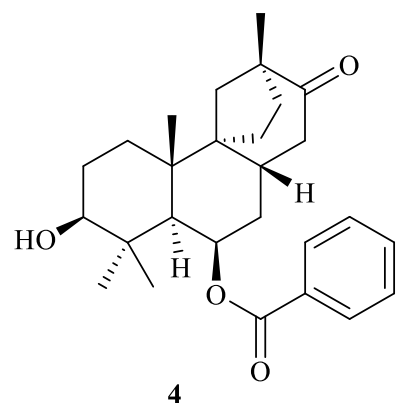

Figure 1. Chemical structures of $\mathbf{1}$ and $\mathbf{2}$ from Scoparia dulcis and two similar analogues.

\section{Results and Discussion}

Compound 1 was assigned the molecular formula $\mathrm{C}_{27} \mathrm{H}_{36} \mathrm{O}_{5}$ by analyses of NMR and HR-ESIMS $\left(\mathrm{m} / \mathrm{z}\right.$ 441.2641, $\left.[\mathrm{M}+\mathrm{H}]^{+}\right)$data, incorporating ten hydrogen deficiencies. The NMR data of (Table 1) 1 clearly showed resonances for a benzoyloxy group as evidenced by $\delta_{\mathrm{H}}$ at $8.04(\mathrm{dd}, J=8.3,1.3 \mathrm{~Hz}$, $2 \mathrm{H}), 7.58(\mathrm{tt}, J=7.4,1.3 \mathrm{~Hz})$ and $7.47(\mathrm{dd}, J=8.3,7.4 \mathrm{~Hz}, 2 \mathrm{H})$, as well as $\delta_{\mathrm{C}}$ at $166.4,133.3,130.6$, $129.7(\times 2)$ and $128.7(\times 2)$. In addition, signals for a ketone $\left(\delta_{\mathrm{C}} 214.0\right)$, two oxygenated methine $\left[\delta_{\mathrm{C}}\right.$ $\left.75.4,70.4 ; \delta_{\mathrm{H}} 4.03(\mathrm{dd}, J=11.3,4.3 \mathrm{~Hz}), 5.59(\mathrm{~m})\right]$, an oxymethylene $\left[\delta_{\mathrm{C}} 70.8 ; \delta_{\mathrm{H}} 3.60\right.$ and 3.11 (both $\mathrm{d}, J=10.8 \mathrm{~Hz})]$ and three singlet methyl $\left[\delta_{\mathrm{C}} 20.6,19.9,14.4 ; \delta_{\mathrm{H}} 1.56,1.07,0.91\right]$ groups were also resolved. The benzoyl and ketone units occupied six hydrogen deficiencies, and the remaining four indicated a tetracyclic skeleton for $\mathbf{1}$. These observations suggested that compound $\mathbf{1}$ could be a scopadulane-type diterpenoid similar to dulcinol [30] (scopadulciol [31]), which was further 
corroborated by detailed examination of 2D NMR data (Figure 2) as described below. Analyses of ${ }^{1} \mathrm{H}-{ }^{1} \mathrm{H}$ COSY correlations afforded four structural fragments of $\mathrm{CH}-1 / \mathrm{CH}_{2}-2 / \mathrm{CH}_{2}-3, \mathrm{CH}-5 / \mathrm{CH}-6 / \mathrm{CH}_{2}-$ $7 / \mathrm{CH}-8 / \mathrm{CH}_{2}-11$ and $\mathrm{CH}_{2}-15 / \mathrm{CH}_{2}-16$, which were subsequently linked with other groups via quaternary carbons by the HMBC correlations from $\mathrm{H}_{3}-20$ to $\mathrm{C}-1, \mathrm{C}-5, \mathrm{C}-9$ and $\mathrm{C}-10, \mathrm{H}_{3}-19$ to C-3, C4, C-5 and C-18, H-11 to C-8, C-9 and C-16, H-14 to C-13, and $\mathrm{H}_{3}-17$ to C-12, C-13 and C-15, to confirm the scopadulane scaffold of $\mathbf{1}$ as shown (Figure 2). The benzoyloxy unit at C-6 was supported by the HMBC correlation from H-6 to C-7' together with the chemical shift for H-6 $\left(\delta_{\mathrm{H}} 5.59\right)$. Lastly, two hydroxy groups were assigned to $\mathrm{C}-1$ and $\mathrm{C}-18$, respectively, based on the chemical shifts for $\mathrm{CH}$ 1 and $\mathrm{CH}_{2}-18$ together with the remaining elements in the molecular formula of $\mathbf{1}$.

Table 1. NMR data for compound $\mathbf{1}$ and the most similar known compounds 3 and $\mathbf{4}$ in $\mathrm{CDCl}_{3}$

\begin{tabular}{|c|c|c|c|c|c|}
\hline & \multicolumn{2}{|r|}{1} & \multirow{2}{*}{$\begin{array}{l}3 \\
\delta_{H}\end{array}$} & \multicolumn{2}{|r|}{4} \\
\hline & $\delta_{\mathrm{C}}$ & $\delta_{H}$ & & $\delta_{\mathrm{C}}$ & $\delta_{H}$ \\
\hline 1 & 75.4 & $4.03, \mathrm{dd}(11.3,4.3)$ & & 32.4 & \\
\hline 2 & 29.5 & $\alpha 1.66, \mathrm{~m}$ & & 27.5 & \\
\hline 3 & 35.3 & $\begin{array}{c}\beta 1.86, \mathrm{~m} \\
\alpha 1.74, \mathrm{~m} \\
\beta 1.19, \mathrm{dt}(13.0,3.3)\end{array}$ & & 79.2 & $3.20, \mathrm{dd}(8.9,6.2)$ \\
\hline 4 & 38.5 & & & 39.8 & \\
\hline 5 & 43.4 & $1.71, \mathrm{~d}(2.3)$ & $1.79, \mathrm{~d}(2)$ & 50.4 & $1.20, \mathrm{~d}(2.2)$ \\
\hline 6 & 70.4 & $5.59, \mathrm{~m}$ & $5.63, \operatorname{td}(3,2)$ & 70.3 & $5.74, \mathrm{q}(2.6)$ \\
\hline 7 & 35.7 & $\begin{array}{l}\beta 1.76, \mathrm{~m} \\
\alpha 1.65, \mathrm{~m}\end{array}$ & $\begin{array}{l}1.81 \text {, ddd }(15,5,3) \\
1.76 \text {, ddd }(15,12,3)\end{array}$ & 35.9 & \\
\hline 8 & 37.4 & $2.46, \mathrm{tt}(11.1,4.8)$ & & 35.8 & $2.47, \mathrm{~m}$ \\
\hline 9 & 53.5 & & & 53.1 & \\
\hline 10 & 44.4 & & & 39.2 & \\
\hline 11 & 48.8 & $\begin{array}{l}\text { a } 2.89, \mathrm{~d}(12.6) \\
\text { b } 1.60, \mathrm{~d}(12.6)\end{array}$ & $\begin{array}{l}1.83, \mathrm{~d}(12) \\
1.54, \mathrm{~d}(12)\end{array}$ & 45.6 & \\
\hline 12 & 52.0 & & & 52.5 & \\
\hline 13 & 214.0 & & & 213.5 & \\
\hline 14 & 42.9 & $\begin{array}{l}\text { a } 2.21, \mathrm{dd}(16.0,6.2) \\
\text { b } 2.02, \mathrm{dd}(16.0,12.1)\end{array}$ & $\begin{array}{l}2.23, \mathrm{dd}(16,12) \\
2.01, \mathrm{dd}(16,6)\end{array}$ & 42.7 & $\begin{array}{l}2.27, \mathrm{dd}(16,6.6) \\
1.98, \mathrm{dd}(16,12)\end{array}$ \\
\hline 15 & 36.8 & $1.75, \mathrm{~m}(2 \mathrm{H})$ & & 36.8 & \\
\hline 16 & 23.4 & $\begin{array}{l}\text { a } 2.28, \mathrm{~m} \\
\text { b } 1.78, \mathrm{~m}\end{array}$ & & 23.9 & $\begin{array}{c}2.10, \text { br t }(9.0) \\
1.72, \mathrm{~m}\end{array}$ \\
\hline 17 & 19.9 & $1.07, \mathrm{~s}$ & $1.09, \mathrm{~s}$ & 19.9 & $1.10, \mathrm{~s}$ \\
\hline 18 & 70.8 & $\begin{array}{l}\text { a } 3.60, \mathrm{~d}(10.8) \\
\text { b } 3.11, \mathrm{~d}(10.8)\end{array}$ & $\begin{array}{l}3.59, \mathrm{~d}(11) \\
3.13, \mathrm{~d}(11)\end{array}$ & 28.5 & $1.11, \mathrm{~s}$ \\
\hline 19 & 20.6 & $0.91, \mathrm{~s}$ & $0.93, \mathrm{~s}$ & 16.8 & $0.97, \mathrm{~s}$ \\
\hline 20 & 14.4 & $1.56, \mathrm{~s}$ & $1.53, \mathrm{~s}$ & 21.4 & $1.51, \mathrm{~s}$ \\
\hline $1^{\prime}$ & 130.6 & & & 130.8 & \\
\hline $2^{\prime} / 6^{\prime}$ & 129.7 & $8.04, \mathrm{dd}(8.3,1.3)$ & 8.02, br d (7.5) & 129.8 & $8.05, \mathrm{~d}(7.6)$ \\
\hline $3^{\prime} / 5^{\prime}$ & 128.7 & $7.47, \mathrm{dd}(8.3,7.4)$ & 7.57, br t $(7.5)$ & 128.8 & 7.47, t (7.6) \\
\hline $4^{\prime}$ & 133.3 & $7.58, \mathrm{tt}(7.4,1.3)$ & 7.45, brt $(7.5)$ & 133.3 & $7.59, \mathrm{t}(7.6)$ \\
\hline $7^{\prime}$ & 166.4 & & & 166.3 & \\
\hline
\end{tabular}

The relative configuration of $\mathbf{1}$ was established by analysis of NOESY data (Figure 2) and proton-proton couplings. In the NOESY spectrum, $\mathrm{H}_{3}-19$ showed correlations with both $\mathrm{H}_{3}-20$ and $\mathrm{H}-$ 2 at $\delta_{\mathrm{H}} 1.86$, suggesting that ring A adopted a chair conformation and this $\mathrm{H}-2, \mathrm{Me}-19$ and Me-20 were 1,3-diaxially bonded. Similarly, the correlations of $\mathrm{H}_{3}-20$ with $\mathrm{H}-8$ and $\mathrm{H}-2^{\prime}\left(6^{\prime}\right)$ also indicated the 


\section{Cytotoxic diterpenoids from the whole plants of Scoparia dulcis}

chair conformation for ring $\mathrm{B}$ and the mutual 1,3-diaxial relationship for $\mathrm{H}-8, \mathrm{Me}-20$, and the benzoyloxy unit. The aforementioned protons and groups were thus co-planar and were assigned to be $\beta$-orientated as in dulcinol [31] (scopadulciol [32]). Then the coupling pattern of $\mathrm{H}-1 / \mathrm{H}-2(J=11.3$ $\mathrm{Hz}, 1,2$-diaxial relationship) and the NOESY correlation of $\mathrm{H}-1 / \mathrm{H}-5$ implied that $\mathrm{H}-1$ and $\mathrm{H}-5$ were $\alpha$ axially located and $1-\mathrm{OH}$ was thus $\beta$-directed. Finally, the NOESY correlations of $\mathrm{H}-8 / \mathrm{H}-11\left(\delta_{\mathrm{H}} 1.60\right)$, $\mathrm{H}-1 / \mathrm{H}-16\left(\delta_{\mathrm{H}} 2.28\right)$ and $\mathrm{H}-7 \alpha / \mathrm{H}-16\left(\delta_{\mathrm{H}} 1.78\right)$ suggested that $\mathrm{CH}_{2}-11$ was in $\beta$-equatorial position and $\mathrm{CH}_{2}-16$ was in $\alpha$-axial position in ring $\mathrm{B}$, which established the relative configuration of the bridge ring as shown. The absolute configuration of 1 was determined to be $(1 R, 4 R, 5 S, 6 R, 8 S, 9 S, 10 S, 12 S)$ by comparing its experimental ECD curve with the calculated one (Figure 3), with a very good match. Moreover, its ECD curve was also consistent with that of a very recently reported analogue, scopadulcic acid D [13]. On reviewing the literature, two compounds with $>95 \%$ similarity to $\mathbf{1}$, namely dulcinol (3) [31] (scopadulciol [32]) and iso-dulcinol (4) [33], were previously described from the same species. Compound $\mathbf{1}$ was identified as the $1 \beta$-hydroxy derivative of dulcinol (3) with extra signals for an oxymethine unit and loss of signals for a methylene group in the NMR spectra. Meanwhile, compared with iso-dulcinol (4), the location of the hydroxy group in ring A of $\mathbf{1}$ shifted to $\mathrm{C}-1$ and the $18-\mathrm{OH}$ was lost in $\mathbf{1}$.

In addition to the new molecule $\mathbf{1}$, another known diterpenoid co-metabolite (2) of the labdane type was also isolated and structurally characterized as scoparinol [31], based on the comparison of spectroscopic data with those in the literature.
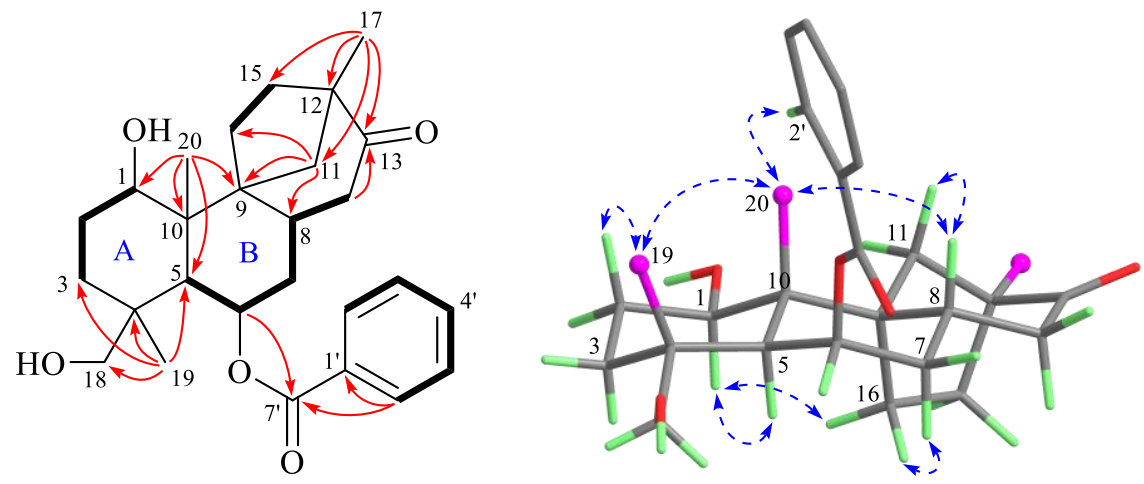

Figure 2. ${ }^{1} \mathrm{H}-{ }^{1} \mathrm{H}$ COSY (bond lines), selected HMBC (arrows) and NOESY (double-headed dashed arrows) correlations for compound $\mathbf{1}$ (For clarity, all methyl groups were simplified to pink balls).

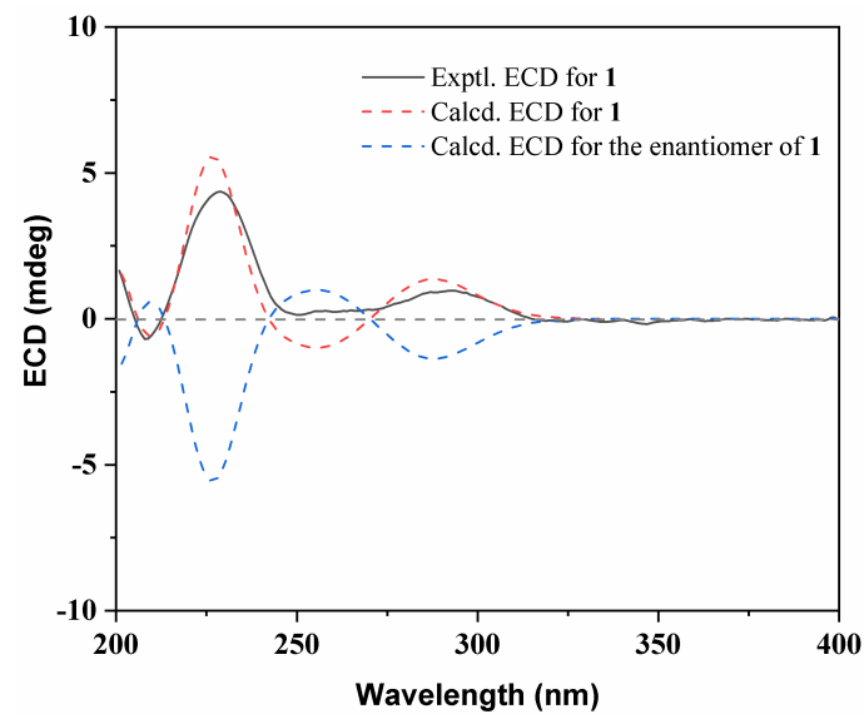

Figure 3. Experimental and calculated ECD spectra for compound 1 
Wang et.al., Rec. Nat. Prod. (2022) 16:5 454-462

Table 2. Cytotoxicity of $\mathbf{1}$ and $\mathbf{2}$ against three female cancer cells ( $\mathrm{IC}_{50}$ in $\left.\mu \mathrm{M}\right)$

\begin{tabular}{cccc} 
& MCF-7 & MDA-MB231 & Hela \\
\hline SAHA & $14.2 \pm 5.64$ & $6.91 \pm 2.22$ & $5.21 \pm 0.54$ \\
$\mathbf{1}$ & $>50$ & $>50$ & $>50$ \\
$\mathbf{2}$ & $45.2 \pm 8.21$ & $26.4 \pm 5.79$ & $8.10 \pm 1.82$ \\
\hline
\end{tabular}
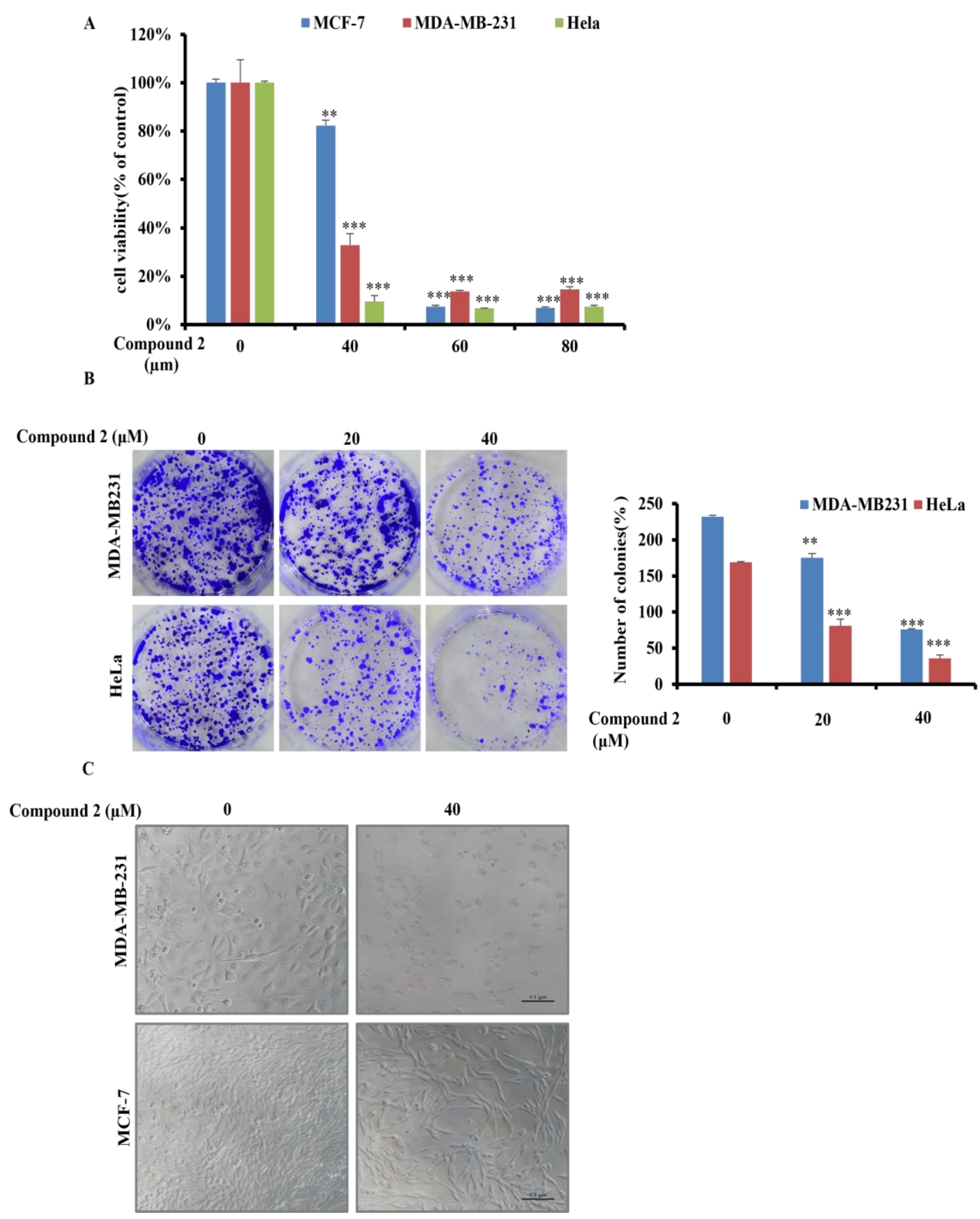

Figure 4. Compound 2 exerts promising anti-breast cancer activity in vitro.

(A) MCF-7, MDA-MB231 and HeLa cells were treated with compound 2, and after $48 \mathrm{~h}$, the MTT assay was performed. The bars indicate the mean \pm SD. (B) MDA-MB231 and HeLa cells were seeded on 6-well plates. After $12 \mathrm{~h}$, cells were treated with indicated concentrations of compound $\mathbf{2}$. On day 10 , the number of colonies was counted in experiments repeated three times. Results represent the average of three replications. (C) MDAMB231 and MCF-7 cells were treated with the indicated concentrations of compound 2 for $24 \mathrm{~h}$. The cell morphologies were detected by interference light microscopy. 


\section{Cytotoxic diterpenoids from the whole plants of Scoparia dulcis}

Compounds 1 and 2 were assessed for their cytotoxicities toward the breast cancer cells (MCF-7 and MDA-MB231), as well as the cervical cancer cells (Hela). As shown in Table 2, compound 2 exhibited different degrees of inhibitory activity against the three cell lines with $\mathrm{IC}_{50}$ values of $45.2 \pm 8.21,26.4 \pm 5.79$ and $8.10 \pm 1.82 \mu \mathrm{M}$, respectively, and suberoylanilide hydroxamic acid (SAHA) was used as a positive control. To further investigate the anticancer activities of compound 2 , the cell viability of the three cancer cells under treatment of compound $\mathbf{2}$ was measured by using MTS assay. As shown in Figure 4A, compound $\mathbf{2}$ significantly inhibited the growth of the tested cancer cells in a dose-dependent manner. Since colony formation is close to the pathological process of tumor cells in vivo, we then performed colony formation assay. As shown in Figure 4B, compound 2 significantly inhibited the cell colony formation in a dose-dependent manner. Furthermore, cell morphology detected by phase-contrast microscope proved that compound $\mathbf{2}$ induced obvious death of cancer cells (Figure 4C). These results demonstrated that compound $\mathbf{2}$ exerts promising anti-breast cancer activity in vitro.

\section{Acknowledgments}

We thank the National Natural Science Foundation of China (No. 91849209, 81803016, 81703360), the Natural Science Foundation of Shandong Province (No. ZR2019HB012), the Qingdao science and technology plan fund (No. RZ1900002629), the Qingdao Applied Basic Research Project (No. 19-6-2-50-cg) and the Postdoctoral Science Foundation of China (No. 2019M650157) for funding supports.

\section{Supporting Information}

Supporting information accompanies this paper on http://www.acgpubs.org/journal/records-ofnatural-products

\section{ORCID}

Lirong Wang: 0000-0001-7154-2016

Jie Yu: 0000-0001-8321-8862

Zonglong Nie: 0000-0002-4439-5054

Peipei Shan: 0000-0002-0553-4728

Lirong

\section{References}

[1] Flora of China Editorial Committee of Chinese Academy of Sciences(1979). Flora of China, Beijing. Science Press. 67(2), 85.

[2] W.T. Wan, Y.J. Song, L.J Xu and P.G. Xiao (2015). An overview on modern research and application potency of Scoparia dulcis, Zhongcaoyao. (in Chinese) 46(16), 2492-2498.

[3] M. Latha and L. Pari (2003). Modulatory effect of Scoparia dulcis in oxidative stress-induced lipid peroxidation in streptozotocin diabetic rats, J. Med. Food. 6, 379-386.

[4] M. Latha and L. Pari (2004). Effect of an aqueous extract of Scoparia dulcis on blood glucose, plasma insulin and some polyol pathway enzymes in experimental rat diabetes, Brazilian J. Med. Biol. Res. 37, 577-586.

[5] S.M.D.F. Freire, J.A.D.S. Emim, A.J. Lapa, C. Souccar and L.M.B. Torres (1993). Analgesic and antiinflammatory properties of Scoparia dulcis L. extracts and glutinol in rodents, Phytother. Res. 7, 408-414.

[6] J.C. Tsai, W.H. Peng, T.H. Chiu, S.C. Lai and C.Y. Lee (2011). Anti-inflammatory effects of Scoparia dulcis L. and betulinic acid, Am. J. Chin. Med. 39, 943-956.

[7] L. Pari and M. Latha (2004). Protective role of Scoparia dulcis plant extract on brain antioxidant status and lipid peroxidation in STZ diabetic male wsitar rats, BMC. Complem. Alternat. Med. 4, 1-8.

[8] A.Y. Coulibaly, M. Kiendrebeogo, P.G. Kehoe, P.A.E.D. Sombie, C.E. Lamien, J.F. Millogo and O.G. Nacoulma (2011). Antioxidant and anti-inflammatory effects of Scoparia dulcis L, J. Med. Food. 14, 1576-1582.

[9] M. Nur-e-Alam, S. Ahmed, M. Yousaf, S. Khan, R. Mothana and A. Al-Rehaily (2020). Isolation and characterization of cytotoxic and anti-inflammatory constituents from Scoparia dulcis L, Journal of Chemical Research. 44(7-8), 381-387. 
[10] K. Hayashi, T. Hayashi and N. Morita (1992). Cytotoxic and antitumor activity of scopadulcic acid from Scoparia dulcis L, Phytotherap. Res. 6(1), 6-9.

[11] M. Ahsan, S.K.N. Islam, A.I. Gray and W. H. Stimson (2003). Cytotoxic diterpenes from Scoparia dulcis, J. Nat. Prod. 66, 958-61.

[12] M.G. Phan, T.S. Phan, K. Matsunami and H. Otsuka (2006). Chemical and biological evaluation on scopadulane-type diterpenoids from Scoparia dulcis of Vietnamese origin, Chem. Pharm Bull. 54, 546549.

[13] L. Dong, W. Sun, Z. Huang, C. Zhang, C. Liu, X. Zhang and S. Zhang (2021). Two new scopadulane diterpenoids from Scoparia dulcis attenuated palmitate-induced viability in MIN6 cells, Fitoterapia 155, 105051.

[14] C.Y. Zhang, L.Z. Chen, Y.Y. Li, N. Wei, L. Zhang, L. Dong, Y. Zhang and X.P. Zhang (2020). Scoparic acid E: a new labdane diterpenoid on attenuating palmitate induced viability in MIN6 cells from Scoparia dulcis, Rec. Nat. Prod. 14(5), 383-386.

[15] W.Y. Sun, Y. Zhang, Y.Y. Li, L.Z. Chen, L. Zhang, C.Y. Zhang and X.P. Zhang (2020). Two new labdane diterpenoids from Scoparia dulcis to attenuate palmitate-induced viability in MIN6 cells, Phytochemistry Letters. 38, 25-27.

[16] K. Hayashi, T. Hayashi (1996). Scopadulciol is an inhibitor of herpes simplex virus type 1 and a potentiator of acyclovir, Antivir. Chem. Chemother. 7, 79-85.

[17] K. Hayashi , S. Niwayama , T. Hayashi, R. Nago, H. Ochiai and N. Morita (1988). In vitro and in vivo antiviral activity of scopadulcic acid B from Scoparia dulcis, Scrophulariaceae, against herpes simplex virus type 1, Antivir. Res. 9, 345-354.

[18] M. Latha , L. Pari , K.M. Ramkumar, P. Rajaguru, T. Suresh, T. Dhanabal, S. Sitasawad and R. Bhonde (2009). Antidiabetic effects of scoparic acid D isolated from Scoparia dulcis in rats with streptozotocininduced diabetes, Nat. Prod. Res. 23, 1528-1540.

[19] Q. Liu, Q.M. Yang, H.J. Hu, L. Yang, Y.P. Yang, G.X. Chou and Z.T. Wang (2014). Bioactive Diterpenoids and Flavonoids from the Aerial Parts of Scoparia dulcis, J. Nat. Prod.. 77(7), 1594-1600.

[20] J.E. Beh, L.T. Khoo, J. Latip, M.P. Abdullah, N.B.M. Alitheen, Z. Adam, A. Ismail and M. Hamid (2013). SDF7, a group of Scoparia dulcis Linn. derived flavonoid compounds, stimulates glucose uptake and regulates adipocytokines in 3T3-F442a adipocytes, J. Ethnopharmacol. 150(1), 339-352.

[21] V.J. Sharma and U.D. Shah(2010). Antihyperglycemic activity of flavonoids from methanolic extract of aerial parts of Scoparia dulcis in streptozotocin induced diabetic rats, Int. J. Chem. Tech Res. 2(1), 214218.

[22] M. Kawasaki, T. Hayashi, M. Arisawa, N. Morita and L.H. Berganza(1988). 8-Hydroxytricetin 7glucuronide, a b-glucuronidase inhibitor from Scoparia dulcis, Phytochemistry 27(11), 3709-11.

[23] Y.S. Li, X.G. Chen, M. Satake, Y. Oshima and Y. Ohizumi (2004). Acetylated Flavonoid Glycosides Potentiating NGF Action from Scoparia dulcis, J. Nat. Prod. 67(4), 725-727.

[24] T. Hayashi, K. Uchida, K. Hayashi, S. Niwayama and N. Morita (1988). A cytotoxic flavone from Scoparia dulcis L. Chem. Pharm. Bull. 36, 4849-4851.

[25] K.R. Sharma1, A. Adhikari, A. Jabeen, , N. Dastagir, S.K. Kalauni, M.I. Choudhary and Y.R. Pokharel (2015). Immunomodulatory Studies on Triterpenoids from Scoparia dulcis Linn, Biochem. Pharmacol. 4, 4. Doi:10.4172/2167-0501.1000182

[26] W.H. Wu, T.Y. Chen, R.W. Lu, S.T. Chen and C.C. Chang (2012). Benzoxazinoids from Scoparia dulcis (sweet broomweed) with antiproliferative activity against the DU-145 human prostate cancer cell line, Phytochemistry 83, 110-115.

[27] Z.K. Jiang, J.H. Sung, X.Y. Wang, Y.Y. Zhang, Y.M. Wang, H.F. Zhou and L. Wen (2021). A review on the phytochemistry and pharmacology of the herb Scoparia dulcis L. for the potentialtreatment of metabolic syndrome, RSC Adv.. 11(50), 31235-31259.

[28] J.H. Yu, Z.P. Yu, Y.Y. Wang, J. Bao, K.K. Zhu, T. Yuan and H. Zhang (2019). Triterpenoids and triterpenoid saponins from Dipsacus asper and their cytotoxic and antibacterial activities, Phytochemistry 162, 241-249.

[29] Q.X. Ma, Q.Q. Xu, J.J. Zhao, W.W. Zhang, Q. Wang, J. Fang, Z.M. Lu, J. Liu and L.N. Ma (2021). Coupling HDAC4 with transcriptional factor MEF2D abrogates SPRY4-mediated suppression of ERK activation and elicits hepatocellular carcinoma drug resistance, Cancer Lett. 520, 243-254.

[30] P.P. Shan, F.F. Yang, H.Z. Qi, Y.J. Hu, S.J. Zhu, Z.Q. Sun, Z. Zhang, C.X. Wang, C.X. Hou, J. Yu, L.R. Wang, Z.X. Zhou, P.F. Li, H. Zhang and K. Wang (2021). Alteration of MDM2 by the small molecule YF438 exerts antitumor effects in triple-negative breast cancer, Cancer Res. 81, 4027-4040.

[31] M. Ahmed and J. Jakupovic (1990). Diterpenoids from Scoparia dulcis, Phytochemistry 29, 3035-3037. 
Cytotoxic diterpenoids from the whole plants of Scoparia dulcis

[32] T. Hayashi, S. Asano, M. Mizutani, N. Takeguchi, T. Kojima, K. Okamura and N. Morita (1991). Scopadulciol, an Inhibitor of Gastric $\mathrm{H}^{+}, \mathrm{K}^{+}$-ATPhase from Scoparia dulcis, and its structure-activity relation-ships, J. Nat. Prod. 54, 802-809.

[33] M. Ahsan, S.K.N. Islam, A.I. Gray and W.H. Stimson (2003). Cytotoxic Diterpenes from Scoparia dulcis, J. Nat. Prod. 66, 958-961.

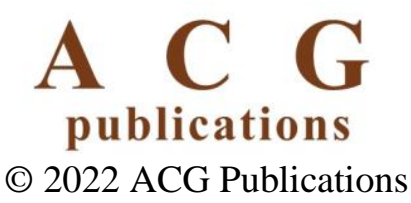

